\title{
Research on Disclosure Status and Influencing Factors of Key Audit Matters
}

\author{
Xin Shao \\ School of Management, Jinan University, Guangzhou, China \\ Email: shaoxin827921@163.com
}

How to cite this paper: Shao, X. (2020). Research on Disclosure Status and Influencing Factors of Key Audit Matters. Modern Economy, 11, 701-725.

https://doi.org/10.4236/me.2020.113052

Received: February 17, 2020

Accepted: March 20, 2020

Published: March 23, 2020

Copyright $\odot 2020$ by author(s) and Scientific Research Publishing Inc. This work is licensed under the Creative Commons Attribution International License (CC BY 4.0).

http://creativecommons.org/licenses/by/4.0/

\begin{abstract}
In 2016, China made new regulations on audit report. The core change is that key audit matters are added to the audit report. Since then, key audit matters have become a new hotspot in the field of audit research. This paper mainly studies the disclosure status of key audit matters in China and the factors affecting the disclosure. This paper will quantify the characteristics of key audit matters and study its impact on the disclosure of key audit matters from the two levels of firm and auditor. This article uses data from listed companies that have disclosed key audit matters from 2016 to 2018, and uses mean testing and regression research methods to analyze how the characteristics of firms and auditors will affect the disclosure of key audit matters. The study found that: 1) the number of key audit matters, the length of the text, the length and proportion of digital figures, and industry-specific key audit matters fluctuated significantly from 2016 to 2017 and stabilized from 2017 to 2018 ; 2) The size of the firm, the audit term, the firm's industry expertise, and the auditor's gender, years of practice, and industry expertise will significantly affect the disclosure of key audit matters. This article provides evidence that the characteristics of firms and auditors affect the disclosure of key audit matters and expands research on key audit matters.
\end{abstract}

\section{Keywords}

Key Audit Matters, Firm Characteristics, Auditor's Personal Characteristics

\section{Introduction}

Audit report is one of the most important channels to realize the communication between investors and auditors, so whether the audit report has information value is very important to the realization of independent audit economic function. But for a long time, in addition to the specific audit opinion, most of the information provided in the audit report is stylized information, so it is also 
called a simple "pass/reject" mode. This mode is simple, uniform and comparable, but lack of pertinence, which is not conducive to alleviate the information asymmetry between the management and the investors. More and more scholars question the content and form of traditional audit report and its value to investors. Especially after the outbreak of the global financial crisis in 2008, the voice of increasing the communication value of audit reports has become increasingly strong. In June 2013, the UK Financial Reporting Council issued the revised auditing standards and took the lead in the reform of auditing reports. Subsequently, the European Commission, the international auditing and Assurance Standards Council (IAASB), the public company accounting oversight committee (PCAOB) of the United States China's Ministry of Finance has issued policies to improve the current audit report mode, and its core change is to increase key audit matters. On December 23, 2016, the Ministry of Finance issued 12 audit standards for Chinese certified public accountants, including "communicating key audit matters in audit reports". Key auditing matters refer to those matters that the certified public accountant considers to be the most important for the audit of the current financial statements according to professional judgment. Key audit matters are selected from matters communicated with governance. The purpose is to improve the information content of audit reports for certified public accountants, meet the demand of capital market reform and development for high-quality accounting information, and maintain the continuous and comprehensive convergence of China's audit standards and international standards. Since then, some articles have appeared to study whether the disclosure of key audit matters will bring information increment and the possible economic consequences of key audit matters, including the impact on audit quality, audit fees and earnings value relevance, etc., but few people have studied what factors will affect the disclosure of key audit matters by firms and auditors.

Based on the background of audit report reform, this paper studies how the characteristics of firms and auditors affect the disclosure of key audit matters from the perspective of influencing factors, so as to examine the impact of key audit matters disclosure and audit report reform from a new perspective. The research of this paper mainly involves the following two aspects: First, the disclosure status of key audit matters. The purpose of studying the disclosure status of key audit matters is to analyze the disclosure characteristics and changes in the past three years on the basis of large samples, grasp the overall situation of key audit matters, and pave the way for the following analysis of influencing factors; Second, how the characteristics of firms and auditors affect the disclosure of key audit matters. In addition to controlling the influencing factors of the company itself, this paper focuses on the influence of the characteristics of the firm and the auditor on the key audit matters. Previous literature has studied audit firm and auditor characteristics, such as the impact of audit firm size on audit quality, the impact of auditor gender, age and industry expertise on audit quality. In the process of audit, firms and auditors also have a certain degree of impact on key audit matters, but it has not been specifically studied how firms 
and auditors will affect and how much. Therefore, the different characteristics of firms and auditors will affect the characteristics of key audit matters.

According to the above introduction, this paper will raise the following three research questions. The first research question of this paper is how to disclose the key audit matters since the implementation of the auditing standards for Chinese certified public accountants No. 1504, communicating the key audit matters in the audit report? Specifically, this paper will analyze the disclosure characteristics of key audit matters from the following aspects: 1) the number of key audit matters; 2) the text length of key audit matters; 3) the digital length of key audit matters and the proportion of the number in the total length; 4) whether the key audit matters reflect the industry shared information or the company specific information. This paper will also analyze the disclosure characteristics and changes of key audit matters in different years.

From the perspective of disclosed key audit matters, when the same company issues the same key audit matters by different firms, its characteristics are different and these differences may be caused by the characteristics of different firms. Therefore, the second research issue of this paper is the impact of firm characteristics on the disclosure characteristics of key audit matters. This paper mainly selects three characteristics of firms, including firm size, firm tenure and firm industry expertise.

When combing the key audit matters, it is found that in addition to the characteristics of the firm will affect the disclosure of key audit matters, different auditors will also affect the disclosure characteristics. When the same company is audited by different auditors of the same firm, there are differences in the characteristics of the key audit matters disclosed. Therefore, the third issue studied in this paper is the impact of the auditor's personal characteristics on the disclosure characteristics of the key audit matters. The auditor's personal characteristics include: gender, professional years and whether he has the industry expertise.

The innovation of this paper is mainly reflected in the following two aspects: First, theoretically, this paper focuses on how auditors disclose key audit matters to cope with the change of standards, and studies the factors affecting the information content of key audit matters, which is different from the previous literature on the economic consequences of key audit matters, and to a certain extent, enriches the research on key audit matters. Second, this paper uses all listed companies that disclose key audit matters in 2016-2018 as research objects, and uses empirical research methods to conduct qualitative and quantitative analysis on the relationship between the disclosure characteristics of key audit matters and the characteristics of firms and auditors, expanding the research on the disclosure characteristics of key audit matters.

\section{Literature Review and Research Questions}

\subsection{Literature Review on Key Audit Matters}

The purpose of the reform of audit report and the increase of key audit matters at home and abroad is to improve the information content and information val- 
ue of audit report. Therefore, there is a literature study on whether the reform of audit report and the disclosure of key audit matters can improve the incremental value of information. Wang, $\mathrm{Xu}$, Wang \& Yu (2018) took listed companies that disclosed key audit items in 2015-2016 as the main research object, and found that the cumulative excess return of companies that disclosed key audit items before and after disclosure was significantly higher than that of companies that did not disclose, indicating that key audit items improved the communication value of audit reports. However, some literature studies have found that disclosure of key audit matters does not necessarily improve communication value and incremental information. Lennox et al. (2019) took the disclosure of material misstatement risk required by the UK as the background, and found that since most of the risks had been known by investors through other channels before disclosure, investors could not find the information increment of the disclosure of material misstatement risk in both short and long window periods, so it was considered that the disclosure of material misstatement risk failed to improve the information value. Ran \& Xu (2017) found that in general, the pilot results of China's audit report met expectations. The new audit report helps to increase information content and improve audit transparency, and also embodies practical innovation in the form and method of disclosure.

In addition to the research on whether the audit report reform or key audit matters can bring incremental information value, there are also research and Analysis on the impact of disclosure of key audit matters or audit report reform on audit quality and audit cost. Reid et al. (2019) takes the reform of audit report in the UK as the background, and proves that the reform of audit report improves the quality of financial report, but does not cause the increase of audit cost, and affirms the significance of the reform of audit report. However, Gutierrez et al. (2018) believe that disclosure of risks alone will not lead to the improvement of audit quality or audit fees, but this conclusion may be because the long-term impact of audit report changes has not been captured. Yan, Zhang \& Huang (2018) used 2015-2016 A-share listed companies as the initial research object, and found that the audit quality of A-share listed companies sharing auditors with $\mathrm{A}+\mathrm{H}$-share companies improved significantly after the issuance of the audit reporting standards for key issues, and the positive impact mainly came from the spillover effect of the common auditors rather than the common accounting firms. Yi Xuan and Mao Yisha (2019) found that after the reform of audit report on key audit matters, the level of accrued earnings management decreased significantly and the audit quality improved.

There are also relevant articles to study the impact of disclosure of key audit matters on investors, company managers and other subjects. Chen, Zhang, Zhang and Niu (2019) found that, compared with companies that did not disclose key audit matters, $\mathrm{A}+\mathrm{H}$-share companies' earnings value relevance decreased significantly after disclosing key audit matters, indicating that the incremental risk information provided by key audit matters attracted investors' attention, en- 
hanced investors' perception of earnings uncertainty, and reduced investors' dependence on earnings in decision-making Lai Chengdu. Christensen et al. (2014) found that disclosure of key audit matters would make nonprofessional investors give up their investment in the company. Cade \& Hodge (2014) found that when the audit reporting standards require auditors to disclose key accounting estimates of enterprises, the experimenters (managers) are not willing to share their private information with the auditors. However, when they only discuss the disclosure of audit procedures, they will not have a negative impact on communication. Some articles have studied the method of eye movement tracking to find that the disclosure of key audit matters will play a guiding role, making the users of audit reports pay more attention to the matters disclosed by key audit matters, but may also ignore other important matters (Sirois \& Bera, 2018). Kang YJ (2019) found that when experienced audit committee members faced with inexperienced shareholders, they would ask more challenging questions to the management. When key audit matters were disclosed in the audit report, this phenomenon was more significant, indicating that the disclosure of key audit matters affected the behavior of the audit committee.

Summing up the foreign literature on key audit matters, it is found that the key audit matters emerged under the wave of audit report reform, whose purpose is to improve transparency and increase information value. Therefore, there are many literature studies on whether audit reports or key audit matters can improve information value, but the academic community has not reached an agreement on this aspect. In addition, another focus is on the impact of disclosure of key audit matters, including the impact on audit quality, audit cost and different subjects. All in all, the previous academic research is mainly about the impact of the disclosure of key audit matters, while few people study how and what factors affect the disclosure of key audit matters.

Some articles also studied the disclosure characteristics of key audit matters. Liu Dan, Chen Juntao (2018) and Lu \& Zhang (2018) comprehensively analyzed the first disclosure of key audit matters in the audit report of $\mathrm{A}+\mathrm{H}$-share listed companies from the aspects of disclosure method, quantity distribution, detailed classification, industry characteristics and firm characteristics, but they did not study the causes of key audit matters Therefore, this paper not only studies the disclosure status of key audit matters, but also analyzes the reasons that affect the disclosure of key audit matters.

\subsection{Literature Review on the Characteristics of Firms and Auditors}

As for the characteristics of the firm, this paper mainly selects three characteristics of firm size, audit tenure and whether it has industry expertise. De Angelo (1981) put forward the theory of firm size and audit quality. He believed that the larger the firm size is, the more quasi rents the clients get, the lower the proportion of quasi rents of single client in the total quasi rents, the stronger the inde- 
pendence of the firm, and the higher the audit quality. However, due to the particularity of China's market, Liu \& Zhou (2007) found that there is no significant difference in the audit quality between the four international and non-international big four in terms of the probability of issuance of non-standard unqualified audit opinions, the number of controllable accruals and the continuity of accounting earnings, which is similar to Yuan \& $\operatorname{Li}$ (2003). Such a conclusion may be similar to our country's unique institutional environment. Secondly, there are some researches on audit tenure and firm industry expertise. Carcello and Nagy (2004) studied the relationship between audit tenure and false financial reports issued by companies. The results showed that companies with audit tenure less than three years were more likely to issue false financial reports than those with long tenure (4 - 8 years), which supported the hypothesis that audit tenure was positively related to audit quality. Bell et al. (2015) found that the audit quality of the firm in the first year of audit was low, and then improved in a very short period of time, but with the audit tenure increasing, the audit quality also declined. Zhang Wangfeng (2018) found that in the top ten firms in China, with the extension of the auditor's tenure, the probability of issuing non-standard unqualified opinions increased significantly, and the audit quality improved significantly. In addition, in the study of industry expertise, Cahan, Jeter \& Naiker (2011) found that when firms have industry expertise through a small number of larger customers in the audit industry, they will maintain high audit quality for reputation reasons, and when firms have industry expertise through more small customers in the audit industry, they will choose the strategy with the lowest cost, that is, to reduce the cost Audit cost leads to the decrease of audit quality. The research and analysis of Ahsan Habib (2011) pointed out that firms' industry expertise can improve audit efficiency through economies of scale, attract more audit and nonaudit businesses, and affect audit fees and audit quality, but the direction of this impact is uncertain. Huinan (2019) studied the relationship between firms, intellectual capital and audit performance, and found that there was a significant positive correlation between industry expertise and audit performance; there was a significant positive correlation between intellectual capital and audit performance; industry expertise can enhance the correlation between intellectual capital and audit performance. Wang, Liu \& Zhang (2017) found that the industry expertise of accounting firms can significantly enhance the positive correlation between fair value and audit fees, and the research conclusions support the hypothesis of product differentiation effect.

In Foreign Studies on auditor's personal characteristics, Lennox CS and Wu X (2018) summarized the literature on auditor's characteristics in recent years, and summarized the influence of six auditor's personal characteristics on audit quality, including auditor's age, auditor's gender, auditor's education, auditor's experience, auditor's expertise and Auditor's moral level. This paper will study the impact of auditor gender, years of practice and industry expertise on the disclosure of key audit matters. First of all, in the study of auditor gender, Hossain \& 
Chapple (2018) found that female auditors are less likely to express going concern opinions for companies with financial difficulties, which shows that female auditors are related to lower audit quality. Hardies, Breesch, and Branson (2015) found that female auditors are related to the obvious audit fee premium, and believed that this audit fee premium reflects the higher ability and knowledge of female auditors and higher customer satisfaction. Secondly, in the study of auditor's practice years, Chen et al. (2016) found that after the firm was transformed into a special general partnership, auditors with a long practice time and older age had relatively weak improvement in accounting conservatism of their audited client companies. Luo et al. (2014) found that rich experience, high position and women's audited financial reports showed higher conservatism respectively, but the positive correlation between experience and accounting conservatism was not significant. Goodwin and $\mathrm{Wu}$ (2016) also found that the older auditors were less likely to issue the first audit opinion of going concern uncertainty, and the older auditors were related to the higher controllable accruals, so the age was negatively related to the audit quality. Li et al. (2012) found that auditor's age, profession and practice time were significantly related to audit expense rate. By reviewing the previous literature, it is found that the number of years of practice represents the auditor's experience and psychology, so auditors with different years of practice may have different disclosure characteristics when facing the disclosure of key audit matters. In addition, whether the auditor has the industry expertise also affects the audit quality. Hsieh, Lin (2016) found that it is the auditor industry expertise rather than the firm industry expertise that filters the customers with high risk, indicating that the auditor industry expertise will affect the customer selection and audit quality. Wang, Song \& Xu (2018) studied the relationship between auditor's personal characteristics and industry expertise, and found that auditor's industry expertise can effectively alleviate the asset mispricing of listed companies, and the impact is more significant when auditor's independence is strong. Han Weifang (2016) found that the richer the experience before the audit year, the better the negotiation ability in the process of setting the initial audit fee. Wei Chunyan (2014) auditor industry expertise may not only inhibit customer tax avoidance, but also encourage customer tax avoidance. Therefore, the auditor's industry expertise may affect the disclosure of key audit matters.

\section{Sample Data and Research Design}

\subsection{Sample Data}

This article selects all listed companies that have disclosed key audit matters from 2016 to 2018 as the initial observations of this article. Due to the uniqueness of the financial industry in financial data, this article will present companies in the financial industry. To improve the effectiveness of the study, companies with missing data in the database and companies with asset-liability ratios greater than 1 or less than or equal to 0 were excluded. All continuous variables in the 
model are truncated at the $1 \%$ level. The data related to financial indicators, firm characteristics, and individual characteristics of the auditors in this article are derived from the CSMAR database, and the data on key audit matters are derived from the CNRDS database, resulting in 14,889 key audit matters. Each company has a number of key audit matters issued each year, so in order to be consistent with other variables during regression, this article will treat the characteristics of 14,889 key audit matters into company-level variables. Combining the disclosure characteristic variables of key audit matters at the company level with other variables, we obtained a company-level sample of 5655 companies.

\subsection{Empirical Model}

As for research question 1, the disclosure characteristics of key audit matters are mainly measured from the following four points: 1) the number of key audit matters disclosed, i.e. the number of key audit matters issued by each company every year; 2) the length of the text, mainly measured by the length of the description and response paragraphs of key audit matters; 3 ) the number, description and response paragraphs of key audit matters The length of the figures in the paragraph and the proportion of the figures in the total length; 4) whether the key audit matters disclosed are industry-specific key audit matters. In order to process the indicators of key audit matters into the company's annual data, this paper will use the method of weighted average of the sum of the key audit matters issued by each company every year.

As for research question 2 and 3, the following models will be used in this paper:

$$
\text { Kam }=\alpha+\beta_{1} \text { Audit_firm }+\beta_{2} \text { Auditor }+\sum \text { Control }+ \text { Industry }+ \text { Year }+\varepsilon_{\text {it }}
$$

Kam represents the disclosure characteristics of key audit matters, The disclosure characteristics of key audit matters are mainly measured from the following four points: 1) the number of key audit matters disclosed, that is, the number of key audit matters issued by each company every year; 2) the length of the text, which is mainly measured by the length of the description section and response section of key audit matters; 3 ) the number, which is included in the description section and response section of key audit matters 4) whether the key audit matters disclosed are industry specific key audit matters. In order to process the indicators of key audit matters into the company's annual data, this paper will use the method of weighted average of the sum of the key audit matters issued by each company every year.

Audit firm represents the characteristics of the firm. The characteristics of the firm are mainly measured from the following three aspects: 1) the size of the firm. As the international four is larger than the domestic firm, and the domestic eight are larger than other domestic firms, it is measured by the international four, domestic eight and other domestic firms; 2) the audit life of the firm, the audit life of the same company by the firm To measure; 3 ) whether the firm has industry expertise. 
Auditor represents the auditor's personal characteristics. There are many auditors' personal characteristics. This paper mainly selects the personal characteristics with relevant research from the following three aspects: 1) auditor's gender; 2) auditor's working years; 3 ) whether the auditor has the professional director.

\subsection{Variable Definition}

According to the above model design, the variables involved in this paper are mainly as follows. Among them, the characteristic variables of the key audit events are the variables at the company level and event level, which need to be processed to obtain the variables at the company level for use in regression. In order to enrich the measurement of the size of the firm, in addition to measuring the size by whether it is the four largest firms, the variable of whether it is the eight largest firms in China will also be included. The variables in the regression model are defined in Table 1 as follows:

Table 1. Variable definitions.

\begin{tabular}{|c|c|c|c|}
\hline \multicolumn{3}{|c|}{ Variables } & Definitions \\
\hline \multirow{12}{*}{ Kam } & \multirow{7}{*}{ Firm_level } & Kam_num & Number of key audit matters issued by each company each year \\
\hline & & Length_sum & Sum of character lengths for all key audit matters issued by each company each year \\
\hline & & Length_unit & Length_sum/Kam_num \\
\hline & & Specificity1_sum & Sum of figures of all key audit matters issued by each company each year \\
\hline & & Specificity1_unit & Specificity1_sum/Kam_num \\
\hline & & Specificity2_sum & Specificity1_sum/Length_sum \\
\hline & & Specificity2_unit & Specificity1_unit/Length_unit \\
\hline & \multirow{5}{*}{ Kam_level } & Ind_spec_sum & Each company is defined as the sum of the number of industry-specific key audit matters each year \\
\hline & & Length & Sum of text length of each key audit matter description paragraph and response paragraph \\
\hline & & Specificity1 & $\begin{array}{l}\text { The sum of the numbers in the description paragraph and the response paragraph of each key } \\
\text { audit matter }\end{array}$ \\
\hline & & Specificity2 & Specificity1/Length \\
\hline & & Ind_spec & $\begin{array}{l}\text { When the key audit event is an industry-specific key audit matter, take } 1 \text {; otherwise, take } 0 \text {; In a } \\
\text { certain industry in each year, the total number of occurrences of a key audit matter is } \\
\text { divided by the total number of companies in the industry in that year. If the ratio is greater than } \\
50 \% \text {, the event is determined to be an industry-specific key audit matter }\end{array}$ \\
\hline \multirow{5}{*}{ Audit_firm } & \multirow{5}{*}{\multicolumn{2}{|c|}{ Audit_firm_spec }} & When the firm is among the four largest in the world, the variable is 1 \\
\hline & & & When the firm is the eight largest in China, the variable is 1 \\
\hline & & & $\begin{array}{l}\text { Firms with industry expertise, variable is } 1 \\
\text { Variables are defined as follows: }\end{array}$ \\
\hline & & & $\mathrm{IMS}_{i k}=\sum_{j=1}^{J} \operatorname{REV}_{i k j} / \sum_{i=1}^{I} \sum_{j=1}^{J} \operatorname{REV}_{i k j}$ \\
\hline & & & $\begin{array}{l}\text { The numerator is the audit fee charged by I accounting firm to the clients of industry } K \text {, and the } \\
\text { denominator is the audit fee of all clients of industry } K \text {. when the IMS of the firm is more than the } \\
\text { median of industry IMS, it is defined that the firm has industry expertise, and the variable is } 1\end{array}$ \\
\hline
\end{tabular}




\section{Continued}

\begin{tabular}{|c|c|c|}
\hline & Audit_tenure & Audit period of a company by the firm, starting from 2009 \\
\hline \multirow[b]{3}{*}{ Auditor } & Gender & When the auditor's gender is male, the variable is 1 \\
\hline & Auditor_year & The auditor's working years \\
\hline & Auditor_spec & $\begin{array}{l}\text { Auditor's industry expertise: the sum of the audit fees of listed companies charged by the internal } \\
\text { auditor of an industry divided by the audit fees of all companies in the industry. If the ratio of the } \\
\text { auditor is greater than the median of the ratio in the industry, the auditor has industry expertise, } \\
\text { and the variable is } 1\end{array}$ \\
\hline \multirow{14}{*}{ Control } & Quick & Quick assets/total assets \\
\hline & Leverage & Total liabilities/total assets \\
\hline & Growth & (Operating revenue of this year - operating revenue of last year)/operating revenue of last year \\
\hline & $\mathrm{Bm}$ & Book to market ratio \\
\hline & Recvinv & $($ Inventory + accounts receivable)/total assets \\
\hline & Otherrec & Other receivables/total assets \\
\hline & Size & Natural logarithm of total assets \\
\hline & Roa & Net profit/total assets \\
\hline & Cfo & Net cash flow from operating activities/total assets \\
\hline & Audittype & If the standard has no reservations, take 1 ; otherwise, take 0 \\
\hline & Age & Years of listing \\
\hline & Loss & If the net profit is negative, take 1 ; otherwise, take 0 \\
\hline & Industry & Industry code of China Securities Regulatory Commission 2012 \\
\hline & Year & Natural year \\
\hline
\end{tabular}

\section{Descriptive Statistics and Mean test}

\subsection{Descriptive Statistics}

\subsubsection{Descriptive Statistics of Disclosure Status of Key Audit Matters}

From the results of Table 2, the number of key audit matters disclosed by the company ranges from 1 to 6 , and most of them are concentrated in about 2 - 3 . More than half of the companies have disclosed 2 key audit matters, and only 4 companies have disclosed 6 key audit matters. The results show that the number of key audit matters is relatively concentrated, and the number of disclosures of most companies is $2-3$.

In order to understand the disclosure characteristics and current situation of key audit matters, 14,889 key audit matters were made descriptive statistics. The results show that on the whole, the maximum length of text is 4081 characters, the minimum is 149 characters, and the average length of disclosed text is 577 characters. The number length is 721 characters at most and 0 characters at least, with an average of 48 characters disclosed each. The ratio of number to text length is 0.407 at most, 0 at least, and 0.087 on average. Of the 14,889 key audit matters, $43.8 \%$ are industry specific key audit matters in Table 3.

\subsubsection{Descriptive Statistics on the Characteristics of Key Audit Matters in 2016-2018}

In order to understand the changes in 2016-2018, Table 4 makes descriptive 
Table 2. Descriptive statistics of Kam_num.

\begin{tabular}{ccccccc}
\hline Kam_num & N & Mean & Sd & Min & P50 & Max \\
\hline 1 & 815 & 1 & 0 & 1 & 1 & 1 \\
2 & 3643 & 1 & 0 & 1 & 1 & 1 \\
3 & 1032 & 1 & 0 & 1 & 1 & 1 \\
4 & 143 & 1 & 0 & 1 & 1 & 1 \\
5 & 18 & 1 & 0 & 1 & 1 & 1 \\
6 & 4 & 1 & 0 & 1 & 1 & 1 \\
Total & 5655 & 1 & 0 & 1 & 1 & 1 \\
\hline
\end{tabular}

Table 3. Descriptive statistics of key audit matters of kam_level.

\begin{tabular}{|c|c|c|c|c|c|c|}
\hline \multicolumn{7}{|c|}{ Panel A: Descriptive statistics for the key audit matter description paragraph } \\
\hline Variable & $\mathrm{N}$ & Mean & Sd & Min & P50 & $\operatorname{Max}$ \\
\hline Length & 14,899 & 258.572 & 111.756 & 26 & 239 & 2881 \\
\hline Specificity1 & 14,899 & 33.210 & 21.354 & 0 & 30 & 477 \\
\hline Specificity2 & 14,899 & 0.134 & 0.071 & 0 & 0.126 & 0.610 \\
\hline Ind spec & 14,899 & 0.438 & 0.496 & 0 & 0 & 1 \\
\hline \multicolumn{7}{|c|}{ Panel B: Descriptive statistics for the key audit matter response paragraph } \\
\hline Variable & $\mathrm{N}$ & mean & sd & $\min$ & p50 & $\max$ \\
\hline Length & 14,889 & 318.483 & 120.249 & 3 & 300 & 2592 \\
\hline Specificity1 & 14,889 & 15.726 & 9.366 & 0 & 14 & 244 \\
\hline Specificity2 & 14,889 & 0.050 & 0.024 & 0 & 0.046 & 0.406 \\
\hline Ind spec & 14,889 & 0.438 & 0.496 & 0 & 0 & 1 \\
\hline \multicolumn{7}{|c|}{ Panel C: General descriptive statistics of key audit matters } \\
\hline variable & $\mathrm{N}$ & mean & sd & $\min$ & $\mathrm{p} 50$ & $\max$ \\
\hline Length & 14,899 & 577.055 & 185.016 & 149 & 548 & 4081 \\
\hline Specificity1 & 14,899 & 48.936 & 24.815 & 0 & 45 & 721 \\
\hline Specificity2 & 14,899 & 0.087 & 0.035 & 0 & 0.083 & 0.407 \\
\hline Ind spec & 14,899 & 0.438 & 0.496 & 0 & 0 & 1 \\
\hline
\end{tabular}

Table 4. Descriptive statistics of disclosure characteristics of key audit matters in 2016-2018.

\begin{tabular}{|c|c|c|c|c|c|c|}
\hline \multicolumn{7}{|c|}{ Panel A: Kam_num } \\
\hline Year & $\mathrm{N}$ & Mean & Sd & Min & $\mathrm{P} 50$ & Max \\
\hline 2016 & 233 & 2.991 & 0.983 & 1 & 3 & 5 \\
\hline 2017 & 7204 & 2.318 & 0.728 & 1 & 2 & 6 \\
\hline 2018 & 7452 & 2.313 & 0.710 & 1 & 2 & 6 \\
\hline \multicolumn{7}{|c|}{ Panel B: Length } \\
\hline Year & $\mathrm{N}$ & Mean & $\mathrm{Sd}$ & Min & $\mathrm{P} 50$ & Max \\
\hline 2016 & 233 & 650.635 & 242.007 & 182 & 613 & 1561 \\
\hline 2017 & 7204 & 557.864 & 176.317 & 149 & 531 & 3422 \\
\hline 2018 & 7452 & 593.307 & 189.028 & 170 & 564 & 4081 \\
\hline
\end{tabular}


Continued

\begin{tabular}{ccccccc}
\hline \multicolumn{7}{c}{ Panel C: Specificityl } \\
\hline Year & $\mathrm{N}$ & Mean & Sd & Min & P50 & Max \\
\hline 2016 & 233 & 62.845 & 31.314 & 12 & 57 & 165 \\
2017 & 7204 & 50.166 & 24.625 & 1 & 47 & 518 \\
2018 & 7452 & 47.312 & 24.566 & 0 & 44 & 721 \\
\hline & & Panel D: Specificity2 & & & \\
\hline Year & $\mathrm{N}$ & Mean & Sd & Min & P50 & Max \\
\hline 2016 & 233 & 0.096 & 0.031 & 0.018 & 0.092 & 0.234 \\
2017 & 7204 & 0.092 & 0.036 & 0.007 & 0.087 & 0.407 \\
2018 & 7452 & 0.081 & 0.034 & 0 & 0.078 & 0.400 \\
\hline & & Panel E: Ind_spec & & & \\
\hline Year & $\mathrm{N}$ & Mean & Sd & Min & P50 & Max \\
\hline 2016 & 233 & 0.811 & 0.392 & 0 & 1 & 1 \\
2017 & 7204 & 0.410 & 0.492 & 0 & 0 & 1 \\
2018 & 7452 & 0.453 & 0.498 & 0 & 0 & 1 \\
\hline
\end{tabular}

statistics on the trend changes of the four aspects of key audit disclosure in 2016-2018. The results are as follows:

According to the results in Table 4, the mean values of Kam_num and Specificityl are decreasing year by year, and the standard error is also decreasing, which shows that the volatility of quantity and digital space decreases with the increase of time, and the mean value is stable at a lower level. The average number of key audit items disclosed decreased from 2.991 in 2016 to 2.313 in 2018, and the average length of figures decreased from 62.845 to 47.312 . Although the Length average value first decreased and then increased in three years, it has been repeated, but the length of 2018 text is far less than that of 2016 text, and its standard error also decreased in three years, indicating that the length of disclosed text tends to be stable from 2016 to 2018. The mean value of Specificity2 also declined over the three years, indicating a decrease in the amount of digital information contained in key audit matters. The average value of Ind_spec has declined from 0.811 in 2016 to 0.435 after 0.41 in 2017, indicating that when the disclosure of key audit matters is required for the first time, most of the key audit matters issued are industry-specific information, and after the first "experience", the key audit matters disclosed in 2017-2018 contain more company personality information.

Generally speaking, when the firm or auditor first disclosed key audit matters in 2016, the standard error of each index was relatively scattered, but in 2017-2018, each index gradually stabilized. This seems to indicate that the firm or auditor is still busy responding to this new requirement in 2016, but after the "testing" or "learning" process, the language is more concise and contains more company information. 


\subsubsection{Descriptive Statistics of Main Variables}

In order to understand the disclosure characteristics of key audit matters at the company level and the variables at other company levels, Table 5 makes descriptive statistics on the variables of all company annual samples. The results are as follows:

Table 5. Descriptive statistics of the variables of firm_level.

\begin{tabular}{|c|c|c|c|c|c|c|c|}
\hline & Variable & $\mathrm{N}$ & Mean & $\mathrm{Sd}$ & Min & p50 & $\operatorname{Max}$ \\
\hline \multirow{8}{*}{$\begin{array}{c}\text { Characteristics } \\
\text { of Kam }\end{array}$} & Kam_num & 5655 & 2.101 & 0.676 & 1 & 2 & 6 \\
\hline & Length_sum & 5655 & 1201.218 & 476.685 & 358 & 1131 & 2846 \\
\hline & Length_unit & 5655 & 573.655 & 140.104 & 310 & 554.667 & 1021.5 \\
\hline & Specificity1_sum & 5655 & 102.465 & 50.350 & 17 & 95 & 282 \\
\hline & Specificity1_unit & 5655 & 48.681 & 18.234 & 14 & 46 & 112.5 \\
\hline & Specificity2_sum & 5655 & 0.182 & 0.083 & 0.035 & 0.173 & 0.457 \\
\hline & Specificity2_unit & 5655 & 0.086 & 0.029 & 0.004 & 0.083 & 0.293 \\
\hline & Ind_spec_sum & 5655 & 0.881 & 0.645 & 0 & 1 & 5 \\
\hline \multirow{4}{*}{$\begin{array}{l}\text { Characteristics } \\
\text { of audit firm }\end{array}$} & Big4 & 5655 & 0.062 & 0.242 & 0 & 0 & 1 \\
\hline & Big8 & 5655 & 0.633 & 0.482 & 0 & 1 & 1 \\
\hline & Audit tenure & 5655 & 5.230 & 2.744 & 1 & 5 & 10 \\
\hline & Audit_firm_spec & 5655 & 0.542 & 0.498 & 0 & 1 & 1 \\
\hline \multirow{3}{*}{$\begin{array}{c}\text { Characteristics } \\
\text { of auditor }\end{array}$} & Gender & 5655 & 0.609 & 0.488 & 0 & 1 & 1 \\
\hline & Auditor_year & 5655 & 10.104 & 5.981 & 1.293 & 9.214 & 24.25 \\
\hline & Auditor_spec & 5655 & 0.544 & 0.498 & 0 & 1 & 1 \\
\hline \multirow{7}{*}{$\begin{array}{c}\text { Other } \\
\text { characteristics } \\
\text { of auditor }\end{array}$} & Rep & 5655 & 0.173 & 0.378 & 0 & 0 & 1 \\
\hline & Degree & 5655 & 0.758 & 0.428 & 0 & 1 & 1 \\
\hline & Major & 5655 & 0.404 & 0.491 & 0 & 0 & 1 \\
\hline & Ccp & 5655 & 0.228 & 0.420 & 0 & 0 & 1 \\
\hline & License & 5655 & 0.992 & 0.091 & 0 & 1 & 1 \\
\hline & Position & 5655 & 0.377 & 0.485 & 0 & 0 & 1 \\
\hline & Partner & 5655 & 0.124 & 0.330 & 0 & 0 & 1 \\
\hline \multirow{12}{*}{ Control } & Roa & 5655 & 0.034 & 0.072 & -0.360 & 0.036 & 0.194 \\
\hline & $\mathrm{Bm}$ & 5655 & 1.176 & 1.213 & 0.119 & 0.775 & 7.231 \\
\hline & Quick & 5655 & 1.779 & 1.769 & 0.191 & 1.221 & 11.22 \\
\hline & Leverage & 5655 & 0.429 & 0.201 & 0.067 & 0.421 & 0.921 \\
\hline & Recvinv & 5655 & 0.269 & 0.161 & 0.009 & 0.252 & 0.719 \\
\hline & Otherrec & 5655 & 0.017 & 0.027 & 0 & 0.008 & 0.175 \\
\hline & Size & 5655 & 22.369 & 1.340 & 19.771 & 22.215 & 26.723 \\
\hline & Groth & 5655 & 0.214 & 0.423 & -0.591 & 0.141 & 2.795 \\
\hline & Loss & 5655 & 0.098 & 0.297 & 0 & 0 & 1 \\
\hline & Age & 5655 & 10.927 & 7.646 & 1 & 8 & 25 \\
\hline & Cfo & 5655 & 0.041 & 0.068 & -0.180 & 0.041 & 0.232 \\
\hline & Audit type & 5655 & 0.963 & 0.190 & 0 & 1 & 1 \\
\hline
\end{tabular}


From the results of descriptive statistics, the sample size at the company level is 5655, and each company discloses about 2 key audit matters on average every year. The average length of key audit items disclosed is 1201 characters, and the average length of unit text is 573 characters. The mean of the number length is 102 , the mean of the unit number length is 48 , the mean of the ratio of the number length to the text length is 0.182 , and the mean of the unit length is 0086. Each company has an average of 0.881 industry-specific key audit matters.

From the descriptive statistics of the characteristics of the firm, the sample size of the four audits is less than $7 \%$ of the overall sample size, and the sample size of the eight audit is $63.3 \%$ of the overall sample size, indicating that the eight audit market share is relatively high. The average audit term of the firm is 5 years, with a maximum of 10 years, indicating that there are companies that have not changed the firm since 2009. About half of the companies are audited by firms with industry expertise. According to the descriptive statistics of auditor characteristics, $60.9 \%$ of auditors are male, and the average practice period of auditors is about 10 years, and the longest practice period is 24 years. More than half of the companies are audited by auditors with industry expertise.

\subsection{Mean Test and Analysis}

Before the regression analysis, the mean test is used to analyze the impact of firm and auditor characteristics on key audit matters. Firstly, the characteristics of the firm are used as grouping variables to test the mean value of the disclosure characteristics of key audit matters. The test results are shown in Table 6 below.

From the above mean test results, the characteristics of the firm have an impact on the disclosure of key audit matters. In terms of the size of the firm, compared with the big eight or other firms, the big four have more, longer and more digital information on key audit matters, but there is no significant difference between the big four and the big eight in the number of disclosures and the proportion of figures. Compared with other firms, the four firms will issue fewer industry-specific key audit matters, indicating that the key audit matters issued by the four firms are more personalized. According to the research of Carcello and Nagy (2004), carcello and Nagy defined the audit term of more than four years as long audit term, and the audit term of less than four years as short audit term, and found that there was a positive correlation between audit term and audit quality. In this paper, the audit term of more than four years is defined as a long audit term, and the audit term of less than four years is defined as a short audit term. When the audit tenure is used as the grouping variable to test the mean value of the characteristics of key audit matters, it is found that the firms with more than four-year audit tenure will issue more, longer and more numbers of key audit matters, and will also issue more industry-specific key audit matters, but in terms of the length of the disclosed unit text, the firms with short audit tenure and long audit tenure are not significant Differences. Firms with industry expertise have longer key audit matters, more digital information and 
Table 6. T-test key audit matters using characteristics of audit firm as grouping variables.

\begin{tabular}{|c|c|c|c|c|c|c|}
\hline \multicolumn{7}{|c|}{ Panel A: Audit firm size and disclosure characteristics of key audit matters } \\
\hline & $\begin{array}{c}\text { Big } 4 \\
(1) \\
\mathrm{N}=352\end{array}$ & $\begin{array}{c}\text { Big } 8 \\
(2) \\
\mathrm{N}=3580\end{array}$ & $\begin{array}{l}\text { Other local } \\
\text { audit firm } \\
\text { (3) } \\
\mathrm{N}=1723\end{array}$ & (1) vs. (3) & (2) vs. (3) & (1) vs.(2) \\
\hline & Mean & Mean & Mean & $\begin{array}{c}\text { Mean } \\
\text { difference }\end{array}$ & $\begin{array}{c}\text { Mean } \\
\text { difference }\end{array}$ & $\begin{array}{c}\text { Mean } \\
\text { difference }\end{array}$ \\
\hline Kam_num & 2.134 & 2.124 & 2.048 & $0.086^{* *}$ & $0.076^{* * *}$ & 0.010 \\
\hline Length_sum & 1328.821 & 1222.213 & 1131.525 & $197.296^{* * *}$ & $90.688^{* * *}$ & $106.608^{\star * *}$ \\
\hline Length_unit & 635.566 & 576.714 & 554.652 & $80.915^{\star * *}$ & $22.063^{* * *}$ & $58.852^{\star * *}$ \\
\hline Specificity1_sum & 119.190 & 104.442 & 94.942 & $24.248^{\star * *}$ & $9.500^{* * *}$ & $14.749^{* * *}$ \\
\hline Specificity1_unit & 57.175 & 48.943 & 46.399 & $10.776^{* * *}$ & $2.544^{\star \star \star}$ & $8.232^{\star \star \star}$ \\
\hline Specificity2_sum & 0.192 & 0.185 & 0.176 & $0.016^{* * *}$ & $0.009^{* * *}$ & 0.007 \\
\hline Specificity2_unit & 0.090 & 0.086 & 0.085 & $0.005^{\star * *}$ & 0.001 & $0.004^{* * *}$ \\
\hline Ind spec_sum & 0.793 & 0.899 & 0.861 & $-0.068^{*}$ & $0.038^{* *}$ & $-0.107^{\star * *}$ \\
\hline
\end{tabular}

Panel B: Tenure of audit firm ${ }^{\mathrm{b}}$ and disclosure characteristics of key audit matters

\begin{tabular}{cccc}
\hline & $\begin{array}{c}\text { Short audit tenure (1) } \\
\mathrm{N}=1962\end{array}$ & $\begin{array}{c}\text { Long audit tenure (2) } \\
\mathrm{N}=3693\end{array}$ & (1) vs (2) \\
\cline { 2 - 4 } & Mean & Mean & Mean difference \\
\hline Kam_num & 2.069 & 2.118 & $-0.049^{\star * *}$ \\
Length_sum & 1181.227 & 1211.838 & $-30.611^{\star *}$ \\
Length_unit & 573.966 & 573.491 & 0.476 \\
Specificity1_sum & 99.470 & 104.057 & $-4.587^{\star * *}$ \\
Specificity1_unit & 47.948 & 49.070 & $-1.122^{\star *}$ \\
Specificity2_sum & 0.178 & 0.185 & $-0.007^{* * *}$ \\
Specificity2_unit & 0.085 & 0.087 & $-0.002^{\star *}$ \\
Ind spec_sum & 0.923 & 0.858 & $0.065^{* * *}$ \\
\hline
\end{tabular}

Panel C: Industry expertise of audit firms and disclosure characteristics of key audit matters

\begin{tabular}{|c|c|c|c|}
\hline & $\begin{array}{l}\text { No industry expertise } \\
\qquad \mathrm{N}=2598\end{array}$ & $\begin{array}{l}\text { Industry expertise (2) } \\
\qquad \mathrm{N}=3066\end{array}$ & (1) vs (2) \\
\hline & Mean & Mean & Mean difference \\
\hline Kam_num & 2.085 & 2.115 & -0.029 \\
\hline Length_sum & 1176.670 & 1221.946 & $-45.276^{\star * *}$ \\
\hline Length_unit & 566.568 & 579.641 & $-13.073^{\star * *}$ \\
\hline Specificity1_sum & 98.710 & 105.636 & $-6.926^{* * *}$ \\
\hline Specificity1_unit & 47.277 & 49.866 & $-2.589^{\star \star \star}$ \\
\hline Specificity2_sum & 0.179 & 0.186 & $-0.007^{\star * \star}$ \\
\hline Specificity2_unit & 0.085 & 0.087 & $-0.002^{\star * *}$ \\
\hline Ind spec_sum & 0.854 & 0.903 & $-0.049^{\star * *}$ \\
\hline
\end{tabular}

a $* * *$ indicates a significance level of $0.01,{ }^{* *}$ indicates a significance level of 0.05 , and ${ }^{*}$ indicates a significance level of $0.1{ }^{b}$ An audit tenure of more than 4 years is a long audit tenure, otherwise it is defined as a short audit tenure. 
more industry-specific key audit matters, but whether they have industry expertise has no significant difference in the number of disclosures.

Secondly, take the personal characteristics of auditors as grouping variables to test the mean value of disclosure characteristics of key audit matters, and the test results are shown in Table 7:

Table 7. T-test key audit matters using characteristics of auditor as grouping variables.

\begin{tabular}{cccc}
\hline \multicolumn{4}{c}{ Panel A: Auditor gender and disclosure characteristics of key audit matters } \\
\hline & $\begin{array}{c}\text { Female auditor (1) } \\
\mathrm{N}=2212\end{array}$ & $\begin{array}{c}\text { Male auditor }(2) \\
\mathrm{N}=3443\end{array}$ & (1) vs (2) \\
\cline { 2 - 4 } & Mean & Mean & Mean difference \\
\hline Kam_num & 2.075 & 2.119 & $-0.044^{* *}$ \\
Length_sum & 1194.339 & 1205.637 & -11.298 \\
Length_unit & 580.229 & 569.432 & $10.797^{* * *}$ \\
Specificity1_sum & 102.876 & 102.201 & 0.675 \\
Specificity1_unit & 49.582 & 48.101 & $1.481^{* * *}$ \\
Specificity2_sum & 0.182 & 0.183 & -0.001 \\
Specificity2_unit & 0.087 & 0.086 & 0.001 \\
Ind spec_sum & 0.880 & 0.881 & -0.001 \\
\hline
\end{tabular}

\begin{tabular}{cccc}
\hline \multicolumn{4}{c}{ Panel B: Tenure of auditor ${ }^{\mathrm{b}}$ and disclosure characteristics of key audit matters } \\
\hline & $\begin{array}{c}\text { Short audit tenure (1) } \\
\mathrm{N}=2830\end{array}$ & $\begin{array}{c}\text { Long audit tenure } \\
\mathrm{N}=2825\end{array}$ & (1) vs (2) \\
\cline { 2 - 4 } & Mean & Mean & Mean difference \\
\hline Kam_num & 2.108 & 2.095 & 0.013 \\
Length_sum & 1226.423 & 1175.968 & $50.455^{\star * *}$ \\
Length_unit & 583.080 & 564.214 & $18.866^{\star * *}$ \\
Specificity1_sum & 104.852 & 100.075 & $4.777^{\star * *}$ \\
Specificity1_unit & 49.578 & 47.781 & $1.797^{\star * *}$ \\
Specificity2_sum & 0.183 & 0.182 & 0.001 \\
Specificity2_unit & 0.086 & 0.086 & 0.000 \\
Ind spec_sum & 0.894 & 0.867 & 0.027
\end{tabular}

Panel C: Industry expertise of auditor and disclosure characteristics of key audit matters

\begin{tabular}{cccc}
\hline & $\begin{array}{c}\text { No industry expertise (1) } \\
\mathrm{N}=2576\end{array}$ & $\begin{array}{c}\text { Industry expertise (2) } \\
\mathrm{N}=3079\end{array}$ & (1) vs (2) \\
\hline Mean & Mean & Mean difference \\
\hline Kam_num & 2.026 & 2.165 & $-0.139^{* * *}$ \\
Length_sum & 1148.694 & 1245.160 & $-96.466^{* * *}$ \\
Length_unit & 568.852 & 577.674 & $-8.822^{* *}$ \\
Specificity1_sum & 96.455 & 107.494 & $-11.039^{* * *}$ \\
Specificity1_unit & 47.409 & 49.744 & $-2.336^{* * *}$ \\
\hline
\end{tabular}




\section{Continued}

\begin{tabular}{|c|c|c|c|}
\hline Specificity2_sum & 0.174 & 0.190 & $-0.016^{\star * *}$ \\
\hline Specificity2_unit & 0.085 & 0.087 & $-0.003^{\star * *}$ \\
\hline Ind spec_sum & 0.893 & 0.871 & 0.022 \\
\hline
\end{tabular}

From the above mean test results, the number of key audit matters disclosed by female auditors is significantly less than that of male auditors, but the mean length of unit text and unit number length disclosed by female auditors is higher than that of male auditors. The length of text and figures disclosed by auditors with short practice years is higher than that of auditors with long practice years. The number, text length, number length and proportion of auditors with industry expertise are higher than those without industry expertise, and whether they have industry expertise does not affect the disclosure of industry-specific key audit matters.

\section{Regression Analysis and Robustness Test}

\subsection{Regression Results and Analysis}

In order to analyze the impact of the characteristics of the firm and auditors on the key audit matters, this article regresses the model of 3.2. The results are shown in Table 8 (1), (2), (3), (4), (5), (6), (7), (8) columns.

From the results in Table 8 , it can be seen that (1) the big 8 audit firm, male and auditors with industry expertise will disclose more key audit matters; (2) the big 4 audit firm and big 8 audit firm and auditors with industry expertise have a significant positive correlation with the total length of on key audit matters, and the impacts of the big 4 audit firm are greatest; (3) The big 4 and big 8 audit firm will positively affect the length of the unit text. The auditor's tenure is negatively related to the length of the unit text, but the coefficient is small. The degree of influence is small; (4) The big 4 and big 8 audit firm and auditors with industry expertise have a positive correlation with the total number of pages, and the big 4 audit firm have the greatest degree of influence; (5) The big 4 audit firm and professional firms and auditors with industry expertise have a positive correlation with and the unit digital space, and male auditors have a negative correlation with the unit digital space; (6) The big 8 audit firm and auditors with industry expertise have a positive correlation on the proportion of digital space in the text; (7) the big 4 audit firm, Tenure of the firm, firms with industry expertise and auditors have a positive impact on the proportion of unit numbers; (8) The big 4 audit firm have a negative correlation with industry-specific key audit matters, and male auditors have a positive correlation with industry-specific key audit matters, indicating that the big 4 audit firms have fewer industry-specific key audit matters, and male have more industry-specific key issues than female, but the impacts of big 4 audit firm are greater. 
Table 8. Impact of audit firm and auditor characteristics on disclosure characteristics of key audit matters.

\begin{tabular}{|c|c|c|c|c|c|c|c|c|}
\hline \multirow{2}{*}{ Variables } & (1) & (2) & (3) & $(4)$ & $(5)$ & $(6)$ & $(7)$ & $(8)$ \\
\hline & Kam_num & Length_sum & Length_unit & Specificity1_sum & Specificity1_unit & t Specificity2_sum & Specificity2_unit & Ind_spec_sum \\
\hline \multirow[t]{2}{*}{ Big 4} & -0.0417 & $88.9787^{* *}$ & $62.3861^{\star * *}$ & $15.3582^{* * *}$ & $9.0973^{\star * *}$ & 0.0082 & $0.0059^{* * *}$ & $-0.1852^{* * *}$ \\
\hline & $(-0.83)$ & $(2.55)$ & $(6.10)$ & $(4.14)$ & $(6.69)$ & $(1.39)$ & $(3.11)$ & $(-4.96)$ \\
\hline \multirow[t]{2}{*}{ Big 8} & $0.0833^{\star * *}$ & $83.5963^{* * *}$ & $17.2352^{\star * *}$ & $6.7086^{* * *}$ & 0.9327 & $0.0061^{\star *}$ & -0.0007 & 0.0302 \\
\hline & $(3.46)$ & $(5.06)$ & $(3.49)$ & $(3.91)$ & (1.48) & $(2.04)$ & $(-0.65)$ & $(1.55)$ \\
\hline \multirow[t]{2}{*}{ Audit_tenure } & -0.0002 & -0.3181 & -0.4226 & 0.3337 & 0.1253 & 0.0006 & $0.0003^{*}$ & -0.0027 \\
\hline & $(-0.07)$ & $(-0.12)$ & $(-0.58)$ & $(1.26)$ & $(1.35)$ & $(1.47)$ & $(1.85)$ & $(-0.97)$ \\
\hline \multirow[t]{2}{*}{ Audit_firm_spec } & -0.0328 & -20.6226 & -1.5931 & 1.0160 & $1.4063^{* *}$ & 0.0014 & $0.0023^{\star *}$ & -0.0038 \\
\hline & $(-1.51)$ & $(-1.35)$ & $(-0.34)$ & $(0.63)$ & $(2.37)$ & $(0.51)$ & $(2.38)$ & $(-0.21)$ \\
\hline \multirow[t]{2}{*}{ Gender } & $0.0333^{*}$ & 15.8221 & -5.6978 & -0.3440 & $-1.0448^{\star \star}$ & 0.0002 & -0.0010 & $0.0264^{*}$ \\
\hline & $(1.83)$ & $(1.26)$ & $(-1.49)$ & $(-0.25)$ & $(-2.08)$ & $(0.09)$ & $(-1.20)$ & $(1.81)$ \\
\hline \multirow[t]{2}{*}{ Auditor_year } & -0.0005 & -1.7523 & $-0.6923^{*}$ & -0.1000 & -0.0269 & 0.0001 & 0.0001 & 0.0010 \\
\hline & $(-0.27)$ & $(-1.33)$ & $(-1.74)$ & $(-0.74)$ & $(-0.54)$ & $(0.41)$ & $(0.69)$ & $(0.69)$ \\
\hline \multirow[t]{2}{*}{ Auditor_spec } & $0.0388^{\star *}$ & $22.8748^{*}$ & 0.7673 & $4.0574^{\star * *}$ & $1.1304^{\star *}$ & $0.0065^{\star * \star}$ & $0.0018^{\star *}$ & -0.0227 \\
\hline & $(2.08)$ & $(1.74)$ & $(0.19)$ & $(2.95)$ & $(2.21)$ & $(2.84)$ & $(2.22)$ & $(-1.47)$ \\
\hline \multirow[t]{2}{*}{ Rep } & $-0.0424^{\star}$ & $-29.9253^{\star}$ & -3.9493 & $-3.6039^{\star *}$ & -0.7964 & $-0.0064^{\star *}$ & -0.0009 & -0.0020 \\
\hline & $(-1.72)$ & $(-1.76)$ & $(-0.78)$ & $(-2.00)$ & $(-1.19)$ & $(-2.14)$ & $(-0.87)$ & $(-0.10)$ \\
\hline \multirow[t]{2}{*}{ Degree } & 0.0277 & $40.4232^{\star * *}$ & $10.8108^{\star *}$ & $6.9263^{* * *}$ & $2.4170^{\star \star *}$ & $0.0084^{\star \star \star}$ & $0.0024^{\star *}$ & 0.0043 \\
\hline & (1.27) & $(2.68)$ & $(2.30)$ & $(4.38)$ & $(4.04)$ & $(3.20)$ & $(2.40)$ & $(0.25)$ \\
\hline \multirow[t]{2}{*}{ Major } & -0.0084 & -2.2657 & 1.1396 & $-2.9050^{\star \star}$ & $-1.2703^{\star \star}$ & $-0.0059^{\star *}$ & $-0.0027^{\star * \star}$ & -0.0013 \\
\hline & $(-0.43)$ & $(-0.17)$ & $(0.27)$ & $(-2.01)$ & $(-2.38)$ & $(-2.45)$ & $(-3.16)$ & $(-0.08)$ \\
\hline \multirow[t]{2}{*}{ Ccp } & 0.0026 & 23.4747 & $10.8733^{\star *}$ & $3.6742^{\star *}$ & $1.5685^{\star * *}$ & 0.0025 & 0.0009 & -0.0091 \\
\hline & $(0.12)$ & $(1.60)$ & $(2.44)$ & $(2.33)$ & $(2.72)$ & $(0.96)$ & $(0.98)$ & $(-0.53)$ \\
\hline \multirow[t]{2}{*}{ License } & -0.0539 & $-145.6347^{\star *}$ & $-48.9073^{\star *}$ & $-15.5557^{\star}$ & $-6.8485^{\star *}$ & -0.0103 & -0.0046 & -0.1114 \\
\hline & $(-0.57)$ & $(-2.01)$ & $(-2.46)$ & $(-1.95)$ & $(-2.09)$ & $(-0.85)$ & $(-0.89)$ & $(-1.55)$ \\
\hline \multirow[t]{2}{*}{ Position } & -0.0001 & $-52.9231^{\star * *}$ & $-25.4690^{\star * *}$ & $-5.2243^{\star \star *}$ & $-2.6428^{\star * *}$ & -0.0010 & -0.0004 & -0.0038 \\
\hline & $(-0.00)$ & $(-3.65)$ & $(-5.69)$ & $(-3.34)$ & $(-4.56)$ & $(-0.40)$ & $(-0.45)$ & $(-0.22)$ \\
\hline \multirow[t]{2}{*}{ Partner } & -0.0033 & 0.5020 & 4.8262 & 0.0399 & 0.2026 & -0.0002 & -0.0003 & 0.0045 \\
\hline & $(-0.10)$ & $(0.02)$ & $(0.74)$ & $(0.02)$ & $(0.23)$ & $(-0.04)$ & $(-0.25)$ & $(0.17)$ \\
\hline \multirow[t]{2}{*}{ Roa } & $-0.9242^{* * *}$ & $-469.4150^{\star * *}$ & 16.8393 & $-50.5876^{* * *}$ & -2.0561 & $-0.0964^{* * *}$ & -0.0092 & $0.5750^{\star * \star}$ \\
\hline & $(-4.10)$ & $(-2.98)$ & $(0.40)$ & $(-3.12)$ & $(-0.40)$ & $(-3.68)$ & $(-1.00)$ & $(3.59)$ \\
\hline \multirow[t]{2}{*}{$\mathrm{Bm}$} & $-0.0252^{\star \star}$ & -12.6127 & -0.6460 & $-2.1163^{\star \star}$ & -0.3123 & $-0.0037^{\star * *}$ & -0.0005 & $0.0286^{\star * *}$ \\
\hline & $(-1.99)$ & $(-1.40)$ & $(-0.24)$ & $(-2.33)$ & $(-0.93)$ & $(-2.60)$ & $(-0.95)$ & $(2.87)$ \\
\hline \multirow[t]{2}{*}{ Quick } & 0.0015 & 0.6009 & 1.0626 & -0.4294 & -0.2536 & -0.0009 & $-0.0006^{\star \star}$ & $0.0116^{\star *}$ \\
\hline & $(0.23)$ & $(0.15)$ & $(0.77)$ & $(-1.02)$ & $(-1.56)$ & $(-1.18)$ & $(-2.32)$ & $(2.25)$ \\
\hline \multirow[t]{2}{*}{ Leverage } & $0.2945^{\star * *}$ & $174.1540^{* * *}$ & 15.8495 & $13.7412^{\star *}$ & -0.6433 & $0.0199^{* *}$ & -0.0037 & $-0.1813^{\star * *}$ \\
\hline & (3.54) & (3.13) & $(0.98)$ & $(2.31)$ & $(-0.31)$ & (2.03) & $(-1.11)$ & $(-2.98)$ \\
\hline
\end{tabular}




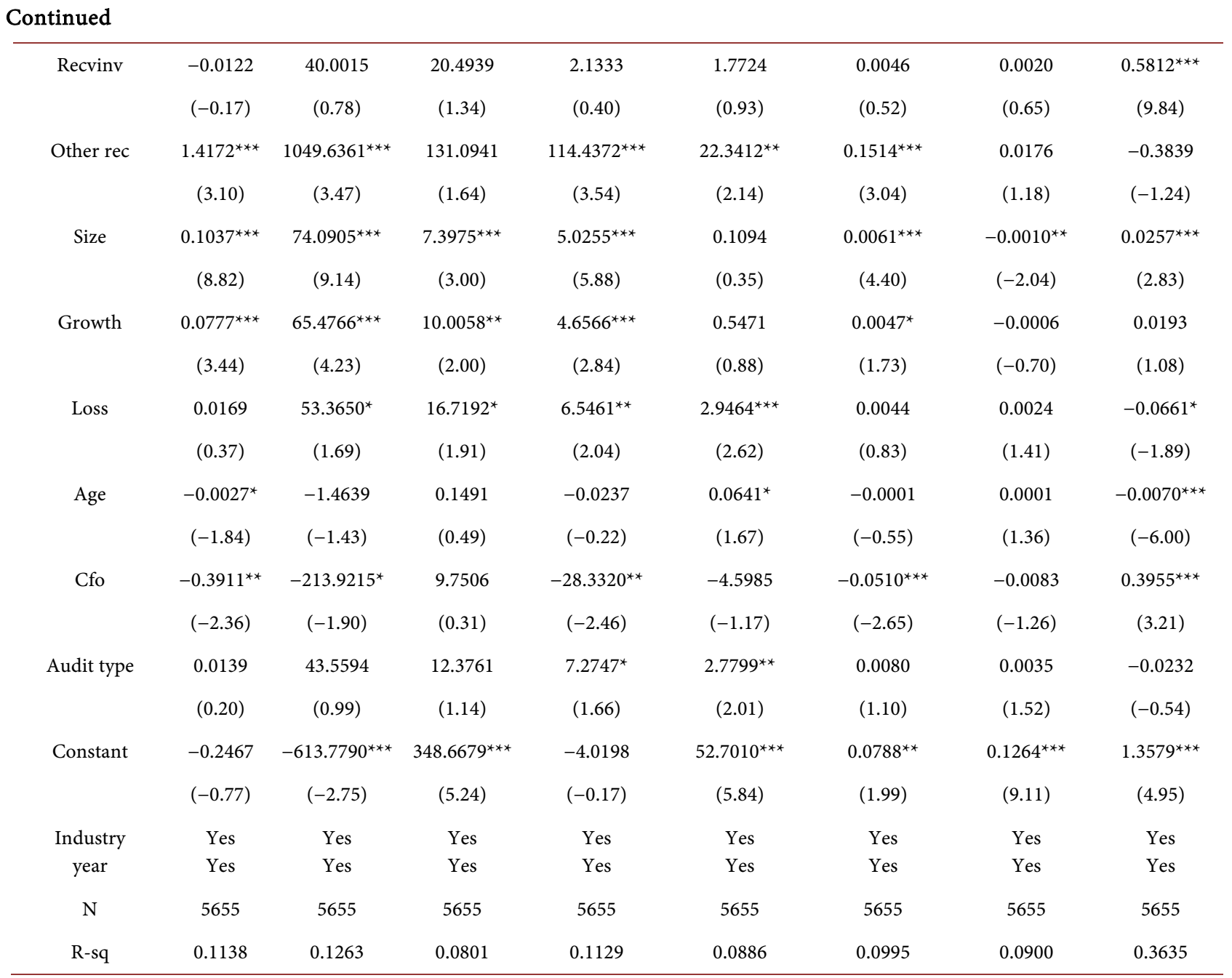

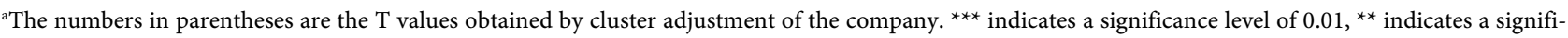
cance level of 0.05 , and ${ }^{*}$ indicates a significance level of 0.1 .

From the regression results, it can be seen that the characteristics of the firm level have more extensive and significant impacts on key audit matters, especially when the firm is the Big 4 , it will disclose key audit matters with longer and more digital information. There is a significant negative correlation with Ind-spec-sum at the $1 \%$ level, indicating that the key audit matters disclosed in the big 4 audit firms disclosures contain more company personality information, which may be due to the higher professionalism and independence of the big 4 audit firms. Disclosure of more company-level information will increase the transparency of audit reports, which also follows the original intention of audit report reform. The big 8 audit firms also have a positive impact on the number, text length, and digital length. However, except for the number, the other impact coefficients are less than the big 4 audit firm impact coefficients, which indicates that the big 4 audit firms have a greater influence on text length and digital length. The scope of the firm's tenure and the firm's industry expertise is relatively small, and only affects the proportion of unit figures and the length of unit 
figures, indicating that the firm's size should be paid more attention when considering the impact of the firm on key audit matters. Compared with male auditors, female auditors disclose smaller numbers, which is consistent with the results of the mean test. The number of years of practice is only related to the length of the unit text. Auditor industry expertise also has a wide-ranging impact on key audit matters, affecting its quantity, length of text, and digital length, which indicates that the industry expertise of the individual auditor has a broader impact than the industry expertise of the firm.

\subsection{Robustness Test}

The definition of firm's industry expertise used in this regression analysis is that when a audit firm's IMS > the median of industry IMS, it is considered that the firm has industry expertise. The same definition of auditor's industry expertise takes the median as the critical value, that is, the sum of the audit fees of listed companies charged by an internal auditor in an industry divided by the audit fees of all companies in the industry. If the ratio of auditors is greater than the median of the ratio in the industry, the auditor has industry expertise. When $75 \%$ is taken as the critical value, the number of firms and auditors with industry expertise will decrease, but firms and auditors judged as having industry expertise will have a stronger "industry brand", which may have an impact on the disclosure of key audit matters.

Replace Audit_firm_spec with Audit_firm_spec 2, and replace Auditor_spec with Auditor_spec 2, then regress after replacing. The results are shown in Table 9. Different from the result of Table 8, after replacing the variables of industry expertise, the audit firms with industry expertise will reduce the number of key audit matters. The influence of firm and auditor characteristics on length, specifityl, specifity 2 and ind_spec is basically the same as that of Table 8 , and slightly different in coefficient. This test is mainly used to define industry expertise with more stringent standards. Firms with industry expertise will reduce the number of disclosures, but will not affect the disclosure of industry-specific key audit matters.

\subsection{Summary of Results}

Since the reform of audit report in 2016, it has gone through three years. In the early stage of audit report reform, the number, text length, digital length of key audit reports and the standard error of industry specific key audit matters are relatively large, which shows that in the early stage of implementation of key audit matters, the data of disclosure characteristics are relatively scattered, indicating that when the firm and audit are faced with the requirements of disclosure of key audit matters for the first time, they are more busy dealing with it than not Form a more consistent situation. In the next two years, the number, text length, digital space and the number of industry-specific matters tend to be stable, which shows that the firms and auditors have gradually adapted to the disclosure of key audit matters. 
Table 9. Use the substitution variable (Audit_firm_spec2 and Auditor_spec2) to regress.

\begin{tabular}{|c|c|c|c|c|c|c|c|c|}
\hline \multirow{2}{*}{ Variables } & (1) & (2) & (3) & $(4)$ & $(5)$ & $(6)$ & $(7)$ & $(8)$ \\
\hline & Kam_num & Length_sum & Length_unit & Specificity1_sum & Specificity1_unit & tSpecificity2_sum & Specificity2_unit & Ind_spec_sum \\
\hline \multirow[t]{2}{*}{ Big 4} & -0.0485 & $82.8757^{\star \star}$ & $61.3069^{\star * *}$ & $15.4248^{\star * *}$ & $9.3390^{* * *}$ & 0.0083 & $0.0064^{* * *}$ & $-0.1858^{\star * *}$ \\
\hline & $(-0.97)$ & $(2.39)$ & $(6.07)$ & $(4.19)$ & $(6.92)$ & $(1.41)$ & $(3.37)$ & $(-5.00)$ \\
\hline \multirow[t]{2}{*}{ Big 8} & $0.0818^{* * *}$ & $80.6117^{\star * *}$ & $15.6892^{\star * *}$ & $7.6835^{\star * *}$ & $1.4930^{* * *}$ & $0.0078^{\star * *}$ & 0.0003 & 0.0266 \\
\hline & $(3.81)$ & $(5.42)$ & $(3.49)$ & $(4.92)$ & $(2.60)$ & $(2.92)$ & $(0.29)$ & $(1.53)$ \\
\hline \multirow[t]{2}{*}{ Audit_tenure } & 0.0003 & -0.1213 & -0.4664 & 0.3948 & 0.1448 & $0.0007^{*}$ & $0.0003^{* *}$ & -0.0031 \\
\hline & $(0.09)$ & $(-0.05)$ & $(-0.64)$ & $(1.49)$ & $(1.57)$ & $(1.70)$ & $(2.10)$ & $(-1.12)$ \\
\hline \multirow[t]{2}{*}{ Audit_firm_spec2 } & $-0.0463^{\star *}$ & -24.2125 & 1.1875 & -1.0394 & 0.6588 & -0.0025 & 0.0009 & 0.0045 \\
\hline & $(-2.24)$ & $(-1.64)$ & $(0.27)$ & $(-0.66)$ & $(1.14)$ & $(-0.97)$ & $(1.06)$ & $(0.27)$ \\
\hline \multirow[t]{2}{*}{ Gender } & $0.0344^{*}$ & 16.4946 & -5.6400 & -0.3498 & $-1.0769^{\star \star}$ & 0.0002 & -0.0010 & $0.0263^{*}$ \\
\hline & $(1.89)$ & $(1.32)$ & $(-1.48)$ & $(-0.26)$ & $(-2.15)$ & $(0.09)$ & $(-1.27)$ & $(1.80)$ \\
\hline \multirow[t]{2}{*}{ Auditor_year } & -0.0005 & -1.7704 & $-0.7025^{\star}$ & -0.0940 & -0.0239 & 0.0001 & 0.0001 & 0.0010 \\
\hline & $(-0.26)$ & $(-1.34)$ & $(-1.77)$ & $(-0.70)$ & $(-0.48)$ & $(0.45)$ & $(0.77)$ & $(0.65)$ \\
\hline \multirow[t]{2}{*}{ Auditor_spec2 } & $0.0390^{*}$ & $30.8614^{\star *}$ & 2.5785 & $4.3333^{* * *}$ & $1.1005^{*}$ & $0.0073^{\star * *}$ & 0.0015 & -0.0165 \\
\hline & $(1.79)$ & (1.99) & $(0.57)$ & $(2.69)$ & $(1.91)$ & $(2.75)$ & $(1.58)$ & $(-0.95)$ \\
\hline \multirow[t]{2}{*}{ Rep } & -0.0400 & $-28.5217^{\star}$ & -3.9630 & $-3.5112^{*}$ & -0.8130 & $-0.0063^{\star \star}$ & -0.0010 & -0.0024 \\
\hline & $(-1.62)$ & $(-1.68)$ & $(-0.78)$ & $(-1.95)$ & $(-1.21)$ & $(-2.08)$ & $(-0.89)$ & $(-0.12)$ \\
\hline \multirow[t]{2}{*}{ Degree } & 0.0272 & $39.8277^{* * *}$ & $10.6718^{* *}$ & $6.9498^{\star * *}$ & $2.4473^{\star * *}$ & $0.0085^{\star * *}$ & $0.0024^{* *}$ & 0.0042 \\
\hline & $(1.25)$ & $(2.64)$ & $(2.27)$ & $(4.39)$ & $(4.09)$ & $(3.21)$ & $(2.46)$ & $(0.24)$ \\
\hline \multirow[t]{2}{*}{ Major } & -0.0094 & -2.8126 & 1.1626 & $-2.9791^{\star *}$ & $-1.2824^{\star *}$ & $-0.0061^{\star *}$ & $-0.0027^{\star * *}$ & -0.0010 \\
\hline & $(-0.48)$ & $(-0.21)$ & $(0.28)$ & $(-2.06)$ & $(-2.40)$ & $(-2.50)$ & $(-3.18)$ & $(-0.06)$ \\
\hline \multirow[t]{2}{*}{ Ccp } & 0.0045 & $24.2955^{\star}$ & $10.7374^{\star \star}$ & $3.7841^{* *}$ & $1.5792^{\star * *}$ & 0.0027 & 0.0009 & -0.0096 \\
\hline & $(0.21)$ & $(1.66)$ & $(2.41)$ & $(2.39)$ & $(2.74)$ & $(1.04)$ & $(1.02)$ & $(-0.56)$ \\
\hline \multirow[t]{2}{*}{ License } & -0.0485 & $-142.9228^{* *}$ & $-49.1188^{\star *}$ & $-15.0913^{\star}$ & $-6.7429^{\star *}$ & -0.0095 & -0.0044 & -0.1138 \\
\hline & $(-0.51)$ & $(-1.97)$ & $(-2.46)$ & $(-1.90)$ & $(-2.06)$ & $(-0.78)$ & $(-0.85)$ & $(-1.58)$ \\
\hline \multirow[t]{2}{*}{ Position } & -0.0007 & $-52.9343^{* * *}$ & $-25.2589^{* * *}$ & $-5.4006^{* * *}$ & $-2.7226^{* * *}$ & -0.0014 & -0.0006 & -0.0031 \\
\hline & $(-0.03)$ & $(-3.65)$ & $(-5.66)$ & $(-3.45)$ & $(-4.70)$ & $(-0.52)$ & $(-0.60)$ & $(-0.17)$ \\
\hline \multirow[t]{2}{*}{ Partner } & -0.0072 & -0.8199 & 4.9558 & -0.2682 & 0.1202 & -0.0006 & -0.0005 & 0.0073 \\
\hline & $(-0.23)$ & $(-0.04)$ & $(0.77)$ & $(-0.11)$ & $(0.14)$ & $(-0.15)$ & $(-0.37)$ & $(0.28)$ \\
\hline \multirow[t]{2}{*}{ Roa } & $-0.9303^{* * *}$ & $-473.4117^{\star * *}$ & 16.7412 & $-51.7580^{* * *}$ & -2.5026 & $-0.0983^{* * *}$ & -0.0099 & $0.5807^{\star * *}$ \\
\hline & $(-4.12)$ & $(-3.01)$ & $(0.40)$ & $(-3.20)$ & $(-0.49)$ & $(-3.76)$ & $(-1.08)$ & $(3.62)$ \\
\hline \multirow[t]{2}{*}{$\mathrm{Bm}$} & $-0.0245^{\star}$ & -11.8979 & -0.5286 & $-2.1353^{\star *}$ & -0.3462 & $-0.0037^{\star * *}$ & -0.0005 & $0.0288^{\star * *}$ \\
\hline & $(-1.93)$ & $(-1.31)$ & $(-0.20)$ & $(-2.34)$ & $(-1.02)$ & $(-2.61)$ & $(-1.08)$ & $(2.89)$ \\
\hline \multirow[t]{2}{*}{ Quick } & 0.0007 & 0.1274 & 1.0446 & -0.4985 & $-0.2694^{*}$ & -0.0010 & $-0.0006^{\star *}$ & $0.0120^{* *}$ \\
\hline & $(0.11)$ & $(0.03)$ & $(0.76)$ & $(-1.18)$ & $(-1.65)$ & $(-1.33)$ & $(-2.41)$ & $(2.33)$ \\
\hline \multirow[t]{2}{*}{ Leverage } & $0.2904^{* * *}$ & $170.8806^{* * *}$ & 15.5216 & $13.4960^{\star *}$ & -0.6490 & $0.0195^{\star *}$ & -0.0037 & $-0.1806^{\star * *}$ \\
\hline & $(3.50)$ & $(3.07)$ & $(0.96)$ & $(2.27)$ & $(-0.31)$ & (1.99) & $(-1.11)$ & $(-2.97)$ \\
\hline
\end{tabular}




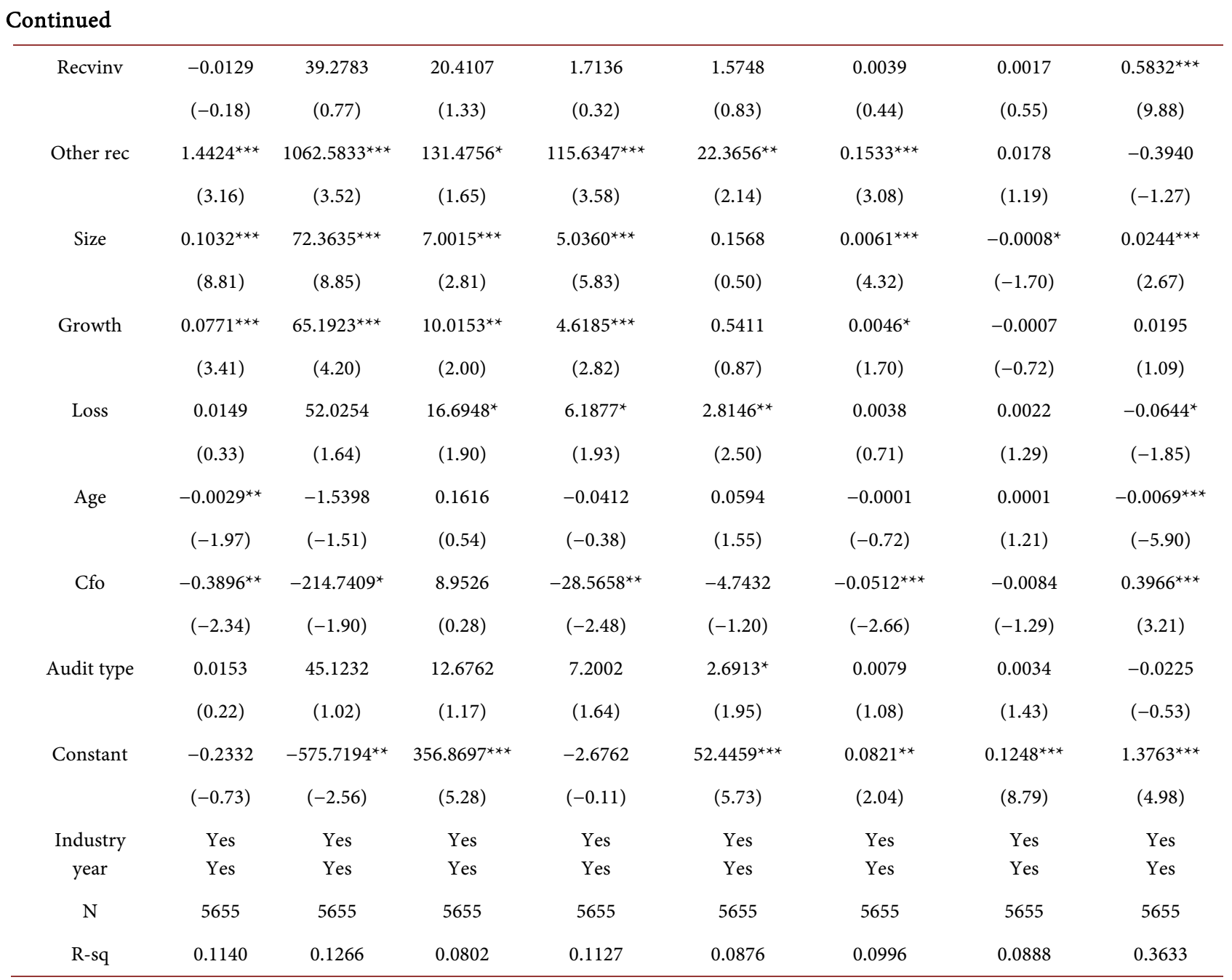

${ }^{a}$ The numbers in parentheses are the $\mathrm{T}$ values obtained by cluster adjustment of the company. ${ }^{* * *}$ indicates a significance level of $0.01,{ }^{* *}$ indicates a significance level of 0.05 , and ${ }^{*}$ indicates a significance level of 0.1 .

When considering the impact of firms and auditors on key audit matters, the impact at the firm level is more prominent, especially the impact of firm size. The key audit matters issued by the four major firms have longer length, more digital information, and more company personality information. The influence of the eight firms on the length of disclosure and the length of figures is second only to that of the four firms, which shows that there is not much difference between the four firms and the eight firms in these two aspects. Audit tenure and industry expertise have little impact on the disclosure characteristics of key audit matters, which shows that compared with audit tenure and industry expertise, the impact of scale on key audit matters is the most important. When considering the auditor's personal characteristics, it is found that the auditor's industry expertise has a wide range of influence. Although it is not as large as the impact of scale on the disclosure characteristics, but compared with the industry expertise at the firm level, the auditor's influence is greater. This shows that it is the auditor's industry expertise at the individual level that affects the audit results. 


\section{Conclusion}

In this paper, the new auditing standards which have been implemented since 2016 in China are used as the starting point, and the key audit matters disclosed in 2016-2018 are used as the research objects to explore the disclosure characteristics of key audit matters and the factors affecting the disclosure of key audit matters in three years, mainly including the impact of the characteristics of the firm and the auditor on the key audit matters. Through the research, we find that the length of the text and the number of key audit matters are relatively scattered, which shows that there are great differences in the text and the number of key audit matters issued by different firms and auditors. The number of key audit matters disclosed is relatively concentrated, and nearly half of them are industry-specific key audit matters, which indicate that firms and auditors will take more account of the nature of the industry when issuing audit reports. In addition, the standard error of each characteristic variable of key audit matters in the first year is relatively large, but it generally declines and tends to be stable in the following two years, which shows that when the firm and auditor first require the disclosure of key audit matters, due to "inadaptability", the disclosure characteristics show a relatively "rich and diverse" trend, while with the development of the It is understood that the firm and auditors have adapted to the requirements for the disclosure of key audit matters, resulting in the concentration of the disclosure characteristics in the past two years.

In order to study what factors affect the disclosure of key audit matters, this paper mainly discusses from the two levels of the firm and the auditor. It is found that the firm level has a greater and wider impact on the disclosure of key audit matters and the size of the firm is particularly important for the disclosure of key audit matters. The auditor's personal characteristics also have a certain impact on the key audit matters, especially the auditor's industry expertise. From this result, we can infer that the characteristics of the firm dominate the disclosure of key audit matters, while the influence of the auditor's personal characteristics is relatively minor, which also reveals the different influences of different levels of the firm and the auditor on the disclosure of key audit matters.

\section{Conflicts of Interest}

The authors declare no conflicts of interest regarding the publication of this paper.

\section{References}

Bell, T. B., Causholli, M., \& Knechel, R. (2015). Audit Firm Tenure, Non-Audit Services, and Internal Assessments of Audit Quality. Journal of Accounting Research, 53, 461-509. https://doi.org/10.1111/1475-679X.12078

http://research.chicagobooth.edu/arc/journal-of-accounting-research/online-suppleme $\underline{\mathrm{nts}}$

Cade, N., \& Hodge, F. (2014). The Effect of Expanding the Audit Report on Managers' Communication Openness. Working Paper. https://doi.org/10.2139/ssrn.2433641 
Cahan, S. F., Jeter, D. C., \& Naiker, V. (2011). Are All Industry Specialist Auditors the Same? Auditing: A Journal of Practice \& Theory, 30, 191-222. https://doi.org/10.2308/ajpt-10181

Carcello, J. V., \& Nagy, A. L. (2004). Audit Firm Tenure and Fraudulent Financial Reporting. Auditing: A Journal of Practice \& Theory, 23, 55-69. https://doi.org/10.2308/aud.2004.23.2.55

Chen, L. H., Zhang, C., Zhang, L. P., \& Niu, Y. L. (2019). Correlation between Disclosure of Key Audit Matters and Earnings Value. Auditing Research, 3, 65-74.

Chen, X. L., Zhang, X. H., \& Yan, H. M. (2016). Audit Firm Transformation, Auditor's Personal Characteristics and Accounting Conservatism. Accounting Research, 6, 77-85.

Christensen, B. E., Glover, S. M., \& Wolfe, C. J. (2014). Do Critical Audit Matter Paragraphs in the Audit Report Change Nonprofessional Investors' Decision to Invest? $\mathrm{Au}$ diting: A Journal of Practice \& Theory, 4, 71-93. https://doi.org/10.2308/ajpt-50793

De Angelo, L. (1981). Auditor Size and Auditor Quality. Journal of Accounting \& Economics, 3, 183-199. https://doi.org/10.1016/0165-4101(81)90002-1

Goodwin, J., \& Wu, D. H. (2016). What Is the Relationship between Audit Partner Busyness and Audit Quality? Contemporary Accounting Research, 33, 341-377. https://doi.org/10.1111/1911-3846.12129

Gutierrez, E., Minutti-Meza, M., Tatum, K. W., \& Maria, V. (2018). Consequences of Adopting an Expanded Auditor's Report in the United Kingdom. Review of Accounting Studies, 23, 1543-1587. https://doi.org/10.1007/s11142-018-9464-0

Habib, A. (2011). Audit Firm Industry Specialization and Audit Outcomes: Insights from Academic Literature. Research in Accounting Regulation, 23, 1-129. https://doi.org/10.1016/j.racreg.2011.06.008

Han, W. F. (2016). Auditor's Personal Experience, Industry Expertise and Audit Fees. Accounting \& Economics Research, 6, 91-108.

Hardies, K., Breesch, D., \& Branson, J. (2015). The Female Audit Fee Premium. Auditing: A Journal of Practice \& Theory, 34, 171-195. https://doi.org/10.2308/ajpt-51079

Hossain, S., \& Chapple, L. (2018). Does Auditor Gender Affect Issuing A Going Concern Opinion? Accounting and Finance, 58, 1027-1036.

Hsieh, Y. T., \& Lin, C. J. (2016). Audit Firms' Client Acceptance Decisions: Does Partner-Level Industry Expertise Matter? Auditing: A Journal of Practice \& Theory, 35, 97-120. https://doi.org/10.2308/ajpt-51292

Hui, N. (2019). Industry Expertise, Intellectual Capital and Audit Performance of Accounting Firms. Finance \& Accounting Monthly, 3, 23-27.

Kang, Y. J. (2019). Are Audit Committees More Challenging Given a Specific Investor Base? Does the Answer Change in the Presence of Prospective Critical Audit Matter Disclosures? Accounting, Organizations \& Society, 77, 1-14. https://doi.org/10.1016/j.aos.2019.04.001

Lennox, C. S., \& Wu, X. (2018). A Review of the Archival Literature on Audit Partners. Accounting Horizons, 32, 1-32. https://doi.org/10.2308/acch-51942

Lennox, C. S., Schmidt, J. J., \& Thompson, A. (2019). Are the Expanded Model of Audit Reporting Informative to Investors? Evidence from the UK. Working Paper.

Li, J. T., Wang, D. M., \& Yang, Y. C. (2012). A Study on the Correlation between Auditor's Personal Characteristics and Audit Expense Rate-Empirical Data from Chinese Listed Companies in 2009. The Chinese Certified Public Accountant, 3, 58-64.

Liu, D., \& Chen, J. T. (2018). Analysis of Key Audit Matters in the New Audit Report-Based on the Audit Report of $\mathrm{A}+\mathrm{H}$ Share Listed Companies. Finance \& Ac- 
counting Monthly, 12, 142-147.

Liu, F., \& Zhou, F. Y. (2007). Does International Big Four Mean High Audit QualityBased on the Test of Accounting Conservatism. Accounting Research, 3, 79-87.

Lu, J., \& Zhang, J. D. (2018). Preliminary Study on Disclosure of Key Audit Matters in Audit Reports-Evidence from A + H Share Listed Companies. Accounting Research, 2, 83-89.

Luo, C. H., Tang, J. X., \& Wang, Y. S. (2014). A Study on the Personal Characteristics of Certified Public Accountants and the Conservatism of Accounting Information. $\mathrm{Au}$ diting Research, 1, 71-78.

Ran, M. D., \& Xu, Y. Z. (2017). Research on the Improvement of Registered Accounting Audit Report-Based on the Sample of Audit Report Reform in China. Auditing Research, 5, 62-69.

Reid, L. C., Carcello, J. V., Li, C., \& Neal, T. L. (2019). Impact of Auditor Report Changes on Financial Reporting Quality \& Audit Costs: Evidence from the United Kingdom. Contemporary Accounting Research, 36, 1501-1539.

https://doi.org/10.1111/1911-3846.12486

Sirois, L. P., \& Bera, P. (2018). The Informational Value of Key Audit Matters in the Auditor's Report: Evidence from an Eye-Tracking Study. Accounting Horizons, 32, 141-162. https://doi.org/10.2308/acch-52047

Wang, S. H., Liu, Z. Q., \& Zhang, Y. (2017). Fair Value, Industry Expertise and Audit Fees. Auditing Research, 2, 48-56.

Wang, S. N., Song, Y. Y., \& Xu, Y. F. (2018). Does the Auditor's Industry Expertise Mitigate Asset Mispricing? Auditing Research, 2, 96-103.

Wang, Y. Y., Xu, R., Wang, C. L., \& Yu, L. S. (2018). Can the Key Audit Matters Increase the Communication Value of the Audit Report? Accounting Research, 6, 86-93.

Wei, C. Y. (2014). Auditor Industry Expertise and Client Tax Avoidance. Auditing Research, 2, 74-83.

Yan, X., Zhang, R. F., \& Huang, J. (2018). Research on the Spillover Effect of Key Audit Reporting Standards. Auditing Research, 6, 75-82.

Yi, X., \& Mao, Y. S. (2019). Reform of Audit Report, Audit Quality \& Audit CostEmpirical Evidence from A $+\mathrm{H}$ Share Market. Finance \& Accounting Monthly, 18, 106-114.

Yuan, H. Q., \& Li, H. J. (2003). Organizational Form, Scale and Audit Quality of Accounting Firms. Auditing Research, 1, 32-37.

Zhang, W. F. (2018). Audit Firm Size, Audit Tenure and Audit Quality. Finance \& Accounting Monthly, 2, 135-142. 